\title{
Effects of irrigation regime and salinity on soil characteristics and yield of tomato
}

\author{
Rita Leogrande, ${ }^{1}$ Ornella Lopedota, ${ }^{1}$ Francesco Montemurro, ${ }^{1}$ Carolina Vitti, ${ }^{2}$ \\ Domenico Ventrella ${ }^{2}$
}

${ }^{1}$ Consiglio per la Ricerca e la sperimentazione in Agricoltura - Unità di ricerca per studio dei sistemi colturali (CRA-SSC), Metaponto (MT); ${ }^{2}$ Consiglio per la Ricerca e la sperimentazione in Agricoltura - Unità di ricerca per i Sistemi Colturali degli Ambienti caldo-aridi (CRA-SCA), Bari, Italy

\begin{abstract}
A field experiment was conducted in Mediterranean conditions to evaluate the effects of different irrigation volumes and water quality on yield performance of tomato crop. The tomato crop was irrigated reestablishing 50 (I1), 75 (I2) and 100\% (I3) of the crop evapotranspiration (ETc) with two water quality: fresh water with EC $0.9 \mathrm{dS} \mathrm{m}^{-1}$ (FW) and saline water with EC $6 \mathrm{dSm}^{-1}(\mathrm{SW})$. At harvest, total and marketable yield, weight, number, total soluble solids (TSS) and dry matter of fruit were calculated, The results showed no statistical differences among the three different irrigation volumes on tomato yield and quality. The salinity treatment did not affect yield, probably because the soil salinity in the root zone on average remained below the threshold of tomato salt tolerance. Instead, salinity improved fruit quality parameters as dry matter and TSS by 13 and 8\%, respectively. After the first field application of saline water, soil saturated extract cations (SSEC), electrical conductivity of soil paste extract (ECe),
\end{abstract}

\footnotetext{
Correspondence: Dr. Rita Leogrande, Consiglio per la Ricerca e la sperimentazione in Agricoltura - Unità di ricerca per studio dei sistemi colturali (CRA-SSC), s.s. 106 Jonica km 448.2, 75010 Metaponto (MT), Italy.

Tel. +39.0835.244424 - Fax: +39.0835 .258349 .

E-mail: rita.leogrande@entecra.it
}

Key words: saline water, irrigation volume, Lycopersicon esculentum, soil solution.

Acknowledgements: : this research was funded by CLIMESCO Evolution of cropping systems as affected by climate change project, contract n. 285, 20/02/2006 (Ministry for Education, University and Research).

The authors would like to thank M. Mastrangelo, R. Scazzarriello, M. Favale, F. Rinaldi and A.R. Quaranta for their skilful technical assisitance.

Received for publication: 1 July 2011.

Accepted for publication: 10 November 2011.

(C) Copyright R. Leogrande et al., 2012

Licensee PAGEPress, Italy

Italian Journal of Agronomy 2012; 7:e8

doi:10.4081/ija.2012.e8

This article is distributed under the terms of the Creative Commons Attribution Noncommercial License (by-nc 3.0) which permits any noncommercial use, distribution, and reproduction in any medium, provided the original author(s) and source are credited. sodium absorption ratio (SAR) and exchangeable sodium percentage (ESP) cations increased; the largest increase of cations, in particular of $\mathrm{Na}$, occurred in the top layer.

At the end of the experiment, the absolute value of SSEC, ECe and SAR, for all the effects studied, were lower than those recorded in 2007. This behavior was suitable to the reduced volumes of treatments administered in 2009 in respect to the 2007. Furthermore, the higher total rainfall recorded in 2009 increased the leaching and downward movement of salts out of the sampling depth.

\section{Introduction}

Tomato (Lycopersicon aesculentum Mill.) is one of the most widely grown vegetables in the world. The quality of the fruits is controlled by the interaction of genetic, environmental, and agronomic factors, including plant nutrition (Dorais et al., 2001). Nutrients concentration and water salinity have a great influence on yields and fruit quality of tomato (Dorais and Papadopoulos, 2000). The plant is classified as moderately sensitive to salinity which means that it tolerates an electrical conductivity of the saturated soil extract (ECe) up to $2.5 \mathrm{dS} \mathrm{m}^{-1}$ without any yield reduction (Maas, 1986). Tomato crop is already grown in large areas where saline conditions are a problem (ReinaSanchez et al., 2005).

An increase in tomato fruit quality with salinity, as total soluble solids content, titratable acidity and perceived fruit flavour, has been observed in several studies (e.g. Sonneveld and van der Burg, 1991; Cuartero and Fernández-Muñoz, 1999; Eltez et al., 2002; Magàn et al. 2008). Fruit size was the only qualitative parameter negatively affected by increasing salinity.

In a field research carried out in Southern Italy, Maggio et al. (2004) found, for tomato irrigated with saline water for more than 10 years, increase of fruit quality (higher acidity, increased soluble solids and higher sugar content), although tomato fruits were smaller than nosalinized control fruits.

In Mediterranean environments, the water resources are limited, the fresh water for agriculture in many regions is little available, so the saline water utilization for irrigation purposes should be developed with optimal management strategies. Such water may contain large quantities of soluble salts, predominately $\mathrm{Ca}$, and $\mathrm{Na}$ ions. The presence of certain cations such as $\mathrm{Na}$ in the irrigation water may create some environmental problems and needs evaluation prior to its use in agriculture. Irrigation with waters that have high concentrations of $\mathrm{Na}$ relative to divalent cations may cause an accumulation of exchangeable Na on soil colloids (Jalali and Merrikhpour, 2008). The successful use of low-quality water depends on soil type and requires the adoption 
of salt tolerant crops or cultivars but also appropriate agronomic practices such as irrigation scheduling, choice of irrigation method, mixture of waters with different salinity or their alternate use. Low-quality water irrigation can affect soil fertility and its physical condition.

In many parts of the world, tomato is cultivated under irrigation (Grange and Andrews, 1994). However, due to the global expansion of irrigated areas and the limited availability of irrigation water, there is need to optimize water use in order to maximize crop yields under water deficit conditions (Fereres and Soriano, 2007). The cultivation without irrigation is possible when the species resistance to abiotic stress (high temperatures and water deficit) was adopted. In fact, Kassam and Smith (2001) reported that several genetically improved varieties, more productive and tolerant to water deficit, have been introduced. Nevertheless, water deficit decreased tomato growth, yield and quality (Byari and $\mathrm{Al}-$ Sayed, 1999) therefore, a proper water management is important for sustainable crop production. Candido et al. (1999) found that water application positively influenced tomato productivity, and in particular the supplementary irrigation increased the marketable yield of $284 \%$, and this value reached 578 and $1327 \%$ with the 50 and $100 \%$ of the maximum crop evapotranspiration. $0 n$ the contrary, the maximum irrigation rate negatively influences the quality, since it induces reductions in soluble solids and dry matter content of tomato crop.

On the light of these considerations, a field research was carried out to evaluate the effects of irrigation regime and water salinity on soil properties and tomato yield in the a Mediterranean environment of Southern Italy.

\section{Materials and methods}

The field experiments were carried out at Metaponto (MT) in Southern Italy $\left(40^{\circ} 24^{\prime} \mathrm{NL} ; 16^{\circ} 48^{\prime} \mathrm{LE}\right)$ from 2007 to 2010 in a private farm and adopting a two-year rotation of tomato and maize. In this paper we reported the results of the summer 2007 and 2009 related to tomato crop. The soil had low content of both nitrogen (N) (1.03 g kg 1) and organic matter $\left(12.1 \mathrm{~g} \mathrm{~kg}^{-1}\right)$. The clay, silt and sand contents were $28.3,40.4$ and $31.3 \%$, respectively; the soil water content at water field capacity $(-0.03 \mathrm{MPa})$ and at permanent wilting point (-1.5 MPa) was 25.6 and $12.3 \%$ (percentage of soil dry weight), respectively.

The climate is accentuated thermomediterranean, according to UNESCO-FAO (1963) classification, with winter temperatures which can fall below $0^{\circ} \mathrm{C}$ and summer ones which can rise above $40^{\circ} \mathrm{C}$, rainfall unevenly distributed during the year, being concentrated mainly in the winter months. During the 2007 tomato growing period the total rainfall was lower than 2009 ( $63.8 \mathrm{~mm}$ and $128 \mathrm{~mm}$ respectively) especially during the fruit set and maturity phases.

The class A pan evaporation rates were greatest during the months of June, July and August, with mean monthly rates of the two years of 242, 333 and $290 \mathrm{~mm}$, respectively. During the experimental trials the average mean temperatures were $24^{\circ} \mathrm{C}$. Four-leaf tomato plants (cv Tomito) were transplanted by hand on the $7^{\text {th }}$ of May of both years on single row (plant densities were of 2 plants $\mathrm{m}^{-2}$ ). The following water quality treatments were compared: fresh water with EC $0.9 \mathrm{dS} \mathrm{m}^{-1}$ (FW) and saline water with EC $6 \mathrm{dS} \mathrm{m}^{-1}$ (SW). The following irrigation treatments were compared: re-establishing 50 (I1), 75 (I2) and 100\% (I3) of the crop evapotranspiration (ETc). The salinity was imposed by irrigating with water artificially salinized, using commercial sea salt ( $97 \%$ of $\mathrm{NaCl}$ ). The experimental layout was a split plot with three replications. Water quality treatments were allocated to the main plots, irrigation rates treatments were arranged in the sub-plots. For statistical analysis the year was considered as strip factor. In all treatments water irrigation was supplied by localized method. The ETc was calculated on the basis of evaporation rate from class A pan (E) (Doorenbos and Pruitt, 1977 ) and the crop coefficients (Kc) applied according to FA0-56 paper (Allen et al., 1998). The E and meteorological data were recorded on hourly basis by an automated data-logger close to the farm. The waterings were carried out when cumulated ETc reached $17.9 \mathrm{~mm}$ from transplanting to blooming and $35.8 \mathrm{~mm}$ from full bloom to fruit ripening corresponding to $40 \%$ of available soil water for a soil depth of 25 $\mathrm{cm}$ from transplanting to blooming and of $50 \mathrm{~cm}$ from full bloom to fruit ripening. The $\mathrm{N}$ dose (180 $\left.\mathrm{kg} \mathrm{ha}^{-1}\right)$ was applied in two times as ammonium sulphate: at transplanting time $\left(60 \mathrm{~kg}\right.$ of $\left.\mathrm{N} \mathrm{ha}^{-1}\right)$ and about one month after transplanting time (120 $\mathrm{kg}$ of $\left.\mathrm{N} \mathrm{ha}^{-1}\right)$. All other agronomic practices were followed as per the recommended package.

\section{Determinations on plant and soil}

\section{Plant}

At harvested (107 and 97 days after transplanting in 2007 and 2009 years, respectively) from each, plot $1 \mathrm{~m}^{2}$ of tomato plants (central row) were collected and the number of fruits, fruit weight, dry matter $(48 \mathrm{~h}$ at $70^{\circ} \mathrm{C}$ ) and total soluble solids (refractometric index ${ }^{\circ}$ Brix) were determined.

\section{Soil sampling}

For each unit plot three soil sub-samples were collected, within interows, for 0-25 cm and 26-50 cm layers at the end of each crop cycle (August 2007 and 2009). The three sub-samples, pooled in one sample for replication, treatment and depth, were air dried, ground to pass a 2$\mathrm{mm}$ sieve and then analysed.

The saturated soil paste extract (SSPE) was prepared using about $120 \mathrm{~g}$ of soil with suitable quantity of distilled water, so that the soil flows from spatula without sticking and then extracted by applying vacuum. The concentration of $\mathrm{K}, \mathrm{Na}, \mathrm{Ca}$ and $\mathrm{Mg}$ on SSPE were determined by ICP-OES (VARIAN Australia Pty Ltd 679 Springvale Road Mulgrave Victoria), whereas, the ECe was determined with a Conductimeter GPL32 CRISON (Crison Strumenti Spa, Carpi, Italy).

The exchangeable cations were determined by extraction in a barium chloride-triethanolamine buffered solution $(\mathrm{pH}=8.2)$, followed ICP-OES determination. The Capacity exchangeable cations (CEC) analysis was performed by the compulsive method, based on saturation with barium-chloride at $\mathrm{pH} 8.2$, displacement of adsorbed barium by excess magnesium $\left(0.05 \mathrm{M} \mathrm{MgSO}_{4}\right)$ and titration of the $\mathrm{Mg}$ remaining in solution with 0.025M EDTA (Ethylenediaminetetraacetic acid) (Page et al., 1982).

The sodium adsorption ratio $\left(\mathrm{SAR}=\left(\mathrm{Na}^{+} /\left(\mathrm{Ca}^{2+}+\mathrm{Mg}^{2+}\right)^{0.5}\right)\right.$ and exchangeable sodium percentage (ESP $=100 \times$ exchangeable $\mathrm{Na}^{+} / \mathrm{CEC}$ ) were also calculated.

\section{Statistical analysis}

Data was analyzed using the SAS package (SAS, 1998). The effects of the treatments were assessed through the General Linear Model procedure. The means of the experimental treatments were compared using the Student-Newman-Keuls (SNK) tests for two and more than two mean comparisons at $\mathrm{P} \leq 0.05$.

For SAR and ESP data, the statistical analysis was carried out by year and considering the soil depth as strip factor.

\section{Results and discussion}

\section{Meteorological conditions}

In Table 1 the irrigation scheduling is reported. The effective rain was $25 \mathrm{~mm}$ and $62 \mathrm{~mm}$ in 2007 and 2009, respectively. In 2009 lower irrigation volumes were due to shorter tomato crop cycle, lower evapo- 
ration rate (-12\% compared to 2007 , data not shown) and higher effective rainfall $(62 \mathrm{~mm}$ respect to $25 \mathrm{~mm})$.

\section{Yield and quality performances of tomato}

In Tables 2, 3 and 4 the main effects on tomato yield performance of irrigation volumes $(I)$, water quality $(W Q)$ and years $(Y)$ are reported with the indications of statistical significance for the following interactions: irrigation volume-year $(I x Y)$, water quality-year $(W Q x Y)$, irrigation volume-water quality ( $I x W Q)$, and irrigation volume-water qualityyear $(I x W Q x Y)$. No significant differences for all quantitative parameters were observed among irrigation and water quality treatments. The average total and marketable yields were 104.3 and $92.4 \mathrm{t} \mathrm{ha}^{-1}$ respectively (Table 2). For the fruit quality irrigation treatments did not affect any parameters.

The lack in reduction of yield as expected in saline treatments is in agreement with the ECe values measured at the end of crop cycles, 4.95 and $2.99 \mathrm{dS} \mathrm{m}^{-1}$ in 2007 and 2009, respectively (Table 5). In fact, the mean ECe of whole crop cycle, probably was around 2-3 $\mathrm{dS} \mathrm{m}^{-1}$ in 2007 and $2 \mathrm{dS} \mathrm{m}^{-1}$ in 2009 . These values are slightly lower or higher than tomato threshold (Maas, 1986). The salinity of irrigation water reduced significantly the mean weight of marketable fruit (-7.6\%) (Table 3 ).

These results are in general agreement with the finding reported by Olympios et al. (2003). Cuartero and Fernández-Muñoz (1999) indicated that the tomato yield can be reduced by decreased average fruit weight and/or by the reduced number of fruits. At relatively low soil electrical conductivity (ECs), the yield reduction observed is caused mainly by a reduction in the average fruit weight whilst the fruit number remains unchanged; the declining number of fruits explains the main portion of yield reduction at higher ECs (van Ieperen, 1996; Cuartero and Soria, 1997). The number of tomato fruits/plant depends on the number of trusses/plant, the number of flowers/truss and the fruit set index (number of fruit/number of flowers) at each truss. The number of trusses/plant is reduced with highly saline irrigation water and with long salinisation periods (Cuartero and Fernández-Muñoz, 1999). Furthermore, in our case overripe fruits harvested in saline treatments resulted significantly higher $(+34 \%)$ than in fresh irrigation water treatment (Table 3).

Significant increases in fruit dry matter percentage were observed in the saline treatment (SW): ripe and green fruit dry matter percent-

Table 1. Waterings and irrigation volumes during tomato growth stages in the two years and for the irrigation treatments.

\begin{tabular}{|c|c|c|c|c|c|c|c|c|}
\hline \multirow[b]{2}{*}{ Treatments } & \multicolumn{2}{|c|}{ I period } & \multicolumn{2}{|c|}{ II period } & \multicolumn{2}{|c|}{ III period } & \multicolumn{2}{|c|}{ Total } \\
\hline & $\begin{array}{c}\text { Waterings } \\
\text { n }\end{array}$ & $\begin{array}{l}\text { Irrigation } \\
\text { volume } \\
\mathrm{m}^{3} \mathrm{ha}^{-1}\end{array}$ & $\begin{array}{c}\text { Waterings } \\
\text { n }\end{array}$ & $\begin{array}{l}\text { Irrigation } \\
\text { volume } \\
\mathrm{m}^{3} \mathrm{ha}^{-1}\end{array}$ & Waterings & $\begin{array}{l}\text { Irrigation } \\
\text { volume } \\
\mathrm{m}^{3} \mathrm{ha}^{-1}\end{array}$ & $\begin{array}{c}\text { Waterings } \\
\text { n }\end{array}$ & $\begin{array}{l}\text { Irrigation } \\
\text { volume } \\
\mathrm{m}^{3} \mathrm{ha}^{-1}\end{array}$ \\
\hline 2007 & & & & & & & & \\
\hline Il & 4 & 337 & 7 & 1270 & 5 & 1036 & 16 & 2643 \\
\hline $\mathrm{I} 2$ & 4 & 505 & 7 & 1905 & 5 & 1554 & 16 & 3964 \\
\hline $\mathrm{I} 3$ & 4 & 674 & 7 & 2540 & 5 & 2072 & 16 & 5286 \\
\hline 2009 & & & & & & & & \\
\hline Il & 5 & 483 & 4 & 764 & 3 & 522 & 12 & 1769 \\
\hline $\mathrm{I} 2$ & 5 & 724 & 4 & 1147 & 3 & 783 & 12 & 2654 \\
\hline I3 & 5 & 965 & 4 & 1527 & 3 & 1044 & 12 & 3536 \\
\hline
\end{tabular}

I period, from transplanting to first fruit cluster formation; II period, from first fruit cluster formation to 10\% of fruits with fully ripe colour; III period, from 10\% of fruits with fully ripe colour to fully ripe.

Table 2. Effects of irrigation volumes, water quality, years, and related interactions on yield performance of tomato.

\begin{tabular}{|c|c|c|c|c|c|}
\hline Treatments & $\begin{array}{l}\text { Total } \\
\text { yield }\end{array}$ & $\begin{array}{c}\text { Marketable } \\
\text { yield }\end{array}$ & $\begin{array}{l}\text { Ripe } \\
\text { fruit } \\
t \text { ha }^{-1}\end{array}$ & $\begin{array}{l}\text { Turn dark- } \\
\text { coloured } \\
\text { fruits }\end{array}$ & $\begin{array}{l}\text { Overripe } \\
\text { fruits }\end{array}$ \\
\hline \multicolumn{6}{|l|}{ Irrigation (I) } \\
\hline Il & 104.2 & 92.4 & 89.0 & 3.4 & 7.1 \\
\hline I2 & 101.3 & 90.5 & 86.4 & 4.1 & 5.4 \\
\hline \multirow[t]{2}{*}{$\mathrm{I} 3$} & 107.2 & 94.3 & 90.8 & 3.5 & 6.7 \\
\hline & ns & ns & ns & ns & ns \\
\hline \multicolumn{6}{|c|}{ Water quality (WQ) } \\
\hline SW & 102.3 & 89.8 & 86.6 & 3.2 & 7.4 \\
\hline \multirow[t]{2}{*}{ FW } & 106.3 & 95.0 & 90.8 & 4.2 & 5.5 \\
\hline & ns & ns & ns & ns & \\
\hline \multicolumn{6}{|l|}{ Years $(Y)$} \\
\hline 2007 & 88.2 & 71.7 & 66.0 & 5.7 & 10.6 \\
\hline 2009 & 120.3 & 113.1 & 111.4 & 1.7 & $\underset{*}{2.2}$ \\
\hline IxY & ns & ns & ns & ns & ns \\
\hline WQxY & ns & ns & ns & ns & ns \\
\hline IxWQ & ns & ns & ns & ns & ns \\
\hline IxWQXY & ns & ns & ns & & ns \\
\hline
\end{tabular}

SW, saline water; FW, fresh water. ${ }^{*} \mathrm{P} \leq 0.05 ;{ }^{* *} \mathrm{P} \leq 0.01 ;{ }^{* * *} \mathrm{P} \leq 0.001$; ns, not significant.
Table 3. Effects of irrigation volumes, water quality, years, and related interactions on average marketable fruit weight and fruit number of tomato.

\begin{tabular}{|c|c|c|c|c|}
\hline Treatments & $\begin{array}{l}\text { Marketable } \\
\text { fruit mean } \\
\text { weight g }\end{array}$ & $\begin{array}{l}\text { Ripe } \\
\text { fruit } \\
n m^{-2}\end{array}$ & $\begin{array}{l}\text { Turn dark- } \\
\text { coloured } \\
\text { fruits } \mathrm{n} \mathrm{m}^{-2}\end{array}$ & $\begin{array}{l}\text { Overripe } \\
\text { fruits } \\
\mathrm{n} \mathrm{m}^{-2}\end{array}$ \\
\hline
\end{tabular}

\section{Irrigation (I)}

\begin{tabular}{lcccc} 
I1 & 15.4 & 563.5 & 39.4 & 64.1 \\
I2 & 15.3 & 552.8 & 41.7 & 55.6 \\
I3 & 14.7 & 610.8 & 34.9 & 64.4 \\
& ns & $n s$ & $n s$ & ns \\
Water quality (WQ) & & & & \\
SW & 14.5 & 585.9 & 35.6 & 69.7 \\
FW & 15.7 & 565.4 & 41.7 & 53.1 \\
& $*$ & ns & ns & ns \\
\hline Years $(Y)$ & & & & \\
2007 & 14.7 & 434.2 & 58.4 & 98.8 \\
2009 & 15.5 & 717.2 & 18.8 & 23.9 \\
& ns & & $* *$ & $*$ \\
IxY & $\mathrm{ns}$ & $\mathrm{ns}$ & $\mathrm{ns}$ & $\mathrm{ns}$ \\
WQxY & $\mathrm{ns}$ & $\mathrm{ns}$ & $\mathrm{ns}$ & $\mathrm{ns}$ \\
IxWQ & $*$ & $\mathrm{~ns}$ & $\mathrm{~ns}$ & $\mathrm{~ns}$ \\
IxWQxY & $\mathrm{ns}$ & $\mathrm{ns}$ & $\mathrm{ns}$ & $\mathrm{ns}$ \\
\hline
\end{tabular}

SW, saline water; FW, fresh water. ${ }^{*} \mathrm{P} \leq 0.05 ;{ }^{* *} \mathrm{P} \leq 0.01 ;{ }^{* * *} \mathrm{P} \leq 0.001 ;$ ns, not significant. 
age increased of 5 and $11 \%$, respectively, compared to fresh water treatment (FW). SW treatment showed the same total fruit dry biomass of FW (Table 4), then the salinity influenced only fruit size whereas it did not reduce the assimilates into the fruits. This reduction of fruit is a consequence of reduction in water content, the low water content of fruit then appears to be the result of an osmotic effect.

SW treatment showed the highest TSS (total soluble solids) content with an increase of about $8 \%$ compared with FW (Table 4 ) that is the most important quality criterion for tomato, confirming the results of many Authors about the positive relationship between brackish water irrigation and quality of tomato (Cuartero and Fernández-Muñoz, 1999; Cucci et al., 2000; Machado et al., 2003; Yurtseven et al., 2005). TSS tends to increase with salinity and hence the use of moderately saline irrigation water (3-6 $\mathrm{dS} \mathrm{m}^{-1}$ ) is recommended to improve fruit quality (Mizrahi et al., 1988). The yield performance showed significant differences in the two years. In particular, the total and marketable yields (Table 2) were lower (88.2 and $71.7 \mathrm{tha}^{-1}$ ) in 2007, because of both low rainfall occurred during fruit setting and maturity phases and a higher temperature recorded during fruit setting. In 2009, higher marketable yield was determined by higher ripe fruit production, due to higher number of ripe fruits and not to average fruit weight. In the same year, the turn dark-coloured fruits and overripe fruits resulted significantly lower compared to 2007, probably due to less ripening variability.

The results of the analysis of variance for the mean weight of marketable fruit indicated a significant $I x W Q$ interaction (Table 3). In fact, this parameter increased with increasing irrigation volumes in the treatment with fresh water, whereas it reduced with enhancing irrigation volumes in the treatment with saline water (Figure 1). In particular, the treatment with re-establishing of $100 \%$ of the ETc (I3) and irrigation with saline water (SW) showed the lowest average marketable fruit (13.3 g). The treatment with re-establishing of 50\% of the ETc (I1) and irrigation with saline water presented an increase of about $16 \%$ compared to I3-SW. This increased was probably due to lower amount of salt supplied in soil with low irrigation volumes.

The results of the analysis of variance for the ripe fruit dry matter percentage showed a significant $I x W Q$ interaction (Table 4 ). In fact,

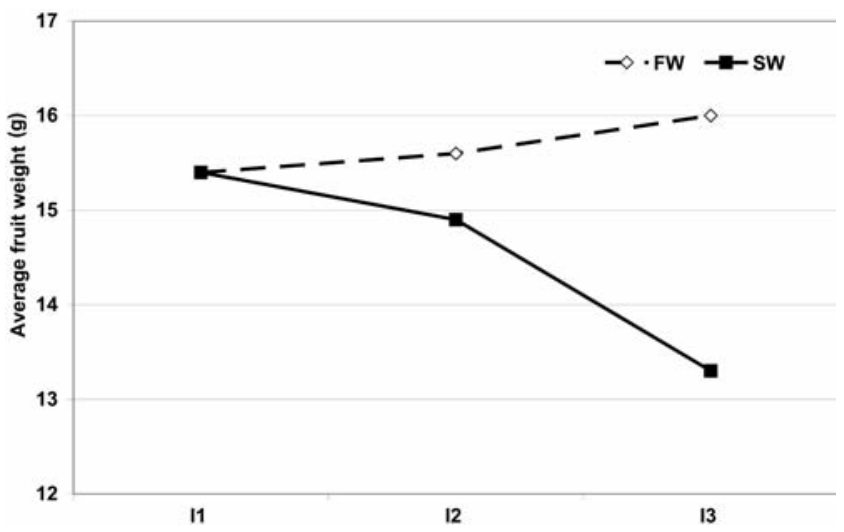

Figure 1. Effect of interaction water quality $x$ irrigation on mean weight of fruits.

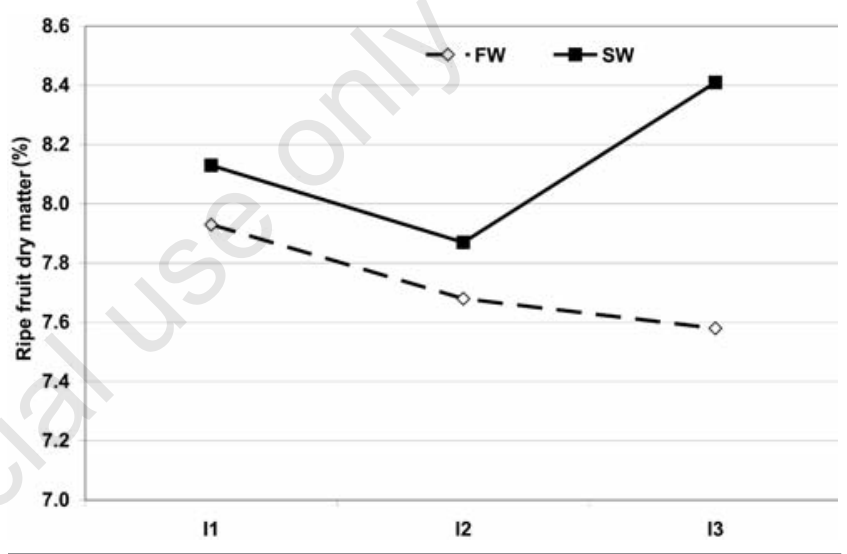

Figure 2. Effect of interaction water quality $x$ irrigation on fruit dry matter percentage.

Table 4. Effects of irrigation volumes, water quality, years, and related interactions on dry matter and total soluble solids of tomato fruits.

\begin{tabular}{|c|c|c|c|c|c|}
\hline Treatments & Ripe & $\begin{array}{l}\text { Fruit dry matter } \\
\text { Turn dark-coloured \% }\end{array}$ & Green & $\begin{array}{c}\text { Dry biomass } \\
\mathrm{t} \mathrm{ha}^{-1}\end{array}$ & $\begin{array}{c}\text { Total soluble solids } \\
{ }^{\circ} \text { Brix }\end{array}$ \\
\hline \multicolumn{6}{|l|}{ Irrigation (I) } \\
\hline Il & 8.0 & 8.7 & 8.5 & 7.5 & 6.6 \\
\hline $\mathrm{I} 2$ & 7.8 & 7.9 & 8.2 & 7.1 & 6.4 \\
\hline \multirow[t]{2}{*}{ I3 } & 8.0 & 9.0 & 8.2 & 7.6 & 6.4 \\
\hline & ns & ns & ns & ns & ns \\
\hline \multicolumn{6}{|c|}{ Water quality (WQ) } \\
\hline SW & 8.1 & 9.1 & 8.7 & 7.4 & 6.7 \\
\hline \multirow[t]{2}{*}{ FW } & 7.7 & 7.9 & 7.8 & 7.4 & 6.2 \\
\hline & $*$ & ns & ${ }^{* *}$ & ns & ${ }^{*}$ \\
\hline \multicolumn{6}{|l|}{ Years $(Y)$} \\
\hline 2007 & 7.5 & 7.4 & 7.9 & 5.3 & 6.4 \\
\hline \multirow[t]{2}{*}{2009} & 8.4 & 9.6 & 8.7 & 9.5 & 6.5 \\
\hline & ${ }^{* *}$ & ns & $*$ & ${ }^{* *}$ & ns \\
\hline $\mathrm{IxY}$ & ns & ns & ns & ns & ns \\
\hline WQxY & ns & ns & ns & ns & ns \\
\hline IxWQ & & ns & ns & ns & ns \\
\hline IxWQxY & ns & ns & ns & ns & ns \\
\hline
\end{tabular}

TSW, saline water; FW, fresh water. ${ }^{*} \mathrm{P} \leq 0.05 ;{ }^{* *} \mathrm{P} \leq 0.01 ;{ }^{* * *} \mathrm{P} \leq 0.001 ;$ ns, not significant. 
Figure 2 shows that this parameter increased with increasing irrigation volumes in the saline water treatment, whereas it reduced with enhancing irrigation volumes in the fresh water one. In particular, the treatment with re-establishing of $100 \%$ of the ETc (I3) and irrigation with saline water (SW) showed the highest ripe fruit dry matter percentage (8.4\%).

As a consequence of the Figures 1 and 2, the fruit average dry matter accumulation was not affected by salinity, in fact the ripe fruit dry percentage increased with increasing irrigation volumes in the treatment with saline water, which probably reduced the fruit water content. Fruits from salt-treated plants seem to grow normally during the cell division phase while deleterious effects of salt are observed during the cell expansion phase (Cuartero and Fernández-Muñoz, 1999). The reduction of the mean weight of marketable fruit could be due to the reduction in water content in the fruit (osmotic effect) and the reduction of the nutrient assimilation caused by a competition among $\mathrm{Na}^{+}-$ $\mathrm{Cl}^{-}$and $\mathrm{K}^{+}, \mathrm{Ca}^{2+}, \mathrm{Mg}^{2+}$ and $\mathrm{NO}_{3}{ }^{-}$(nutritional effect). In fact, I3 treatment reached the highest EC and SAR values in the 2009 with an increase of about $30 \%$ and $36 \%$ compared to I1 (Table 5).

The treatments I1, I2 and I3 showed the same marketable yield because number of fruits did not show significant differences and the lower mean weight of marketable fruit in the treatment with re-establishing of $100 \%$ of the ETc (I3) and irrigation with saline water (SW) was compensated by the treatment with re-establishing of $100 \%$ of the ETc (I3) and irrigation with fresh water (FW).

\section{Effects on soil}

SSPE analysis and exchangeable properties of soil are shown in Table 5 by years (2007 and 2009) in function of soil depth $(D)$, water quality $(W Q)$, and irrigation regime $(I)$. The statistical significance of the following interactions are also reported: $D x W Q, D x I, W Q x I$ and DxWQxI. In 2007, no significant differences between depths were found for all SSPE cations except for Na that decreased (-11.4\%) in the deeper layer compared to the top one. This could be mainly due to higher Na solubility compared to other cations and to higher irrigation supplied in 2007 (Table 1). Calcium dominated the exchangeable complex followed by magnesium, sodium and potassium. The high exchangeable $\mathrm{Ca}$ and $\mathrm{Mg}$ content was due to a preferential and stronger adsorption of these divalent cations over monovalent ( $\mathrm{Na}$ and $\mathrm{K}$ ). However, also in this case, exchangeable Na value decreased in the deeper layer in respect to the top one, as well as the ESP value (25.3 and 29.1\%, respectively). The CEC showed an increase in the deeper layer of $4.4 \%$ in respect to the top one. This result is in agreement with that reported by Sunitha et al. (2010).

As expected, significant differences were found for $W Q$ for $\mathrm{Na}, \mathrm{ECe}$ and SAR of soil saturated extract. In particular in SW Na increased by 4.4 times, ECe and SAR by 3.7 times compared to FW. Again this behavior was confirmed for exchangeable Na and ESP value. Moreover in SW $\mathrm{Ca}$ and $\mathrm{Mg}$ showed a decrease of 16 and 26\%, respectively, compared to FW treatment. These results are in agreement with those reported by Jalali and Merrikhpour (2008). They found that the addition of the poor

Table 5. Effects of depth, water quality and irrigation on saturation extract and exchangeable properties of soil.

\begin{tabular}{|c|c|c|c|c|c|c|c|c|c|c|c|c|c|}
\hline & & & & & Soil s & ution & & & & changeable ca & tions & & \\
\hline Effect & levels & & & $\mathrm{Ca}$ & Mg & ECe & SAR & $\mathbf{K}$ & $\mathrm{Na}$ & $\mathrm{Ca}$ & Mg & $\mathrm{CEC}$ & ESP \\
\hline & & & & & & $\mathrm{dS} \mathrm{m}^{-1}$ & & & & meq $100 \mathrm{~g}^{-1}$ & $\%$ & & \\
\hline & & & & & & & 2007 & & & & & & \\
\hline Depth (D) & $0-25$ & 35.8 & 485.7 & 139.6 & 31.0 & 3.07 & 10.17 & 1.45 & 2.61 & 11.37 & 2.58 & 19.07 & 13.80 \\
\hline & $26-50$ & 48.6 & 430.1 & 162.9 & 34.7 & 3.22 & 7.87 & 1.45 & 1.95 & 11.55 & 2.34 & 19.92 & 9.79 \\
\hline & & ns & & ns & ns & ns & ns & ns & & ns & $*$ & * & $*$ \\
\hline Water quality (WQ) & FW & 30.1 & 167.9 & 106.5 & 25.3 & 1.34 & 3.84 & 1.35 & 0.71 & 12.46 & 2.83 & 19.46 & 3.66 \\
\hline & SW & 54.3 & 747.8 & 196.1 & 40.4 & 4.95 & 14.20 & 1.55 & 3.85 & 10.46 & 2.09 & 19.52 & 19.93 \\
\hline & & & $* * *$ & ns & ns & $* *$ & $* *$ & ns & & & & ns & $* * *$ \\
\hline Irrigation (I) & I1 & 43.1 & 521.5 & 155.6 & 32.9 & 3.52 & 9.87 & 1.41 & $2.64 \mathrm{a}$ & 11.38 & 2.35 & 18.88 & $14.27 \mathrm{a}$ \\
\hline & I2 & 39.9 & 467.1 & 133.6 & 29.4 & 3.33 & 9.81 & 1.40 & $2.59 \mathrm{a}$ & 11.63 & 2.49 & 19.55 & $13.23 \mathrm{a}$ \\
\hline & $\mathrm{I} 3$ & 43.6 & 385.1 & 164.5 & 36.3 & 2.59 & 7.38 & 1.54 & $1.61 \mathrm{~b}$ & 11.36 & 2.53 & 20.05 & $7.88 \mathrm{~b}$ \\
\hline & & ns & ns & ns & ns & ns & ns & ns & $* *$ & ns & $\mathrm{ns}$ & ns & $* * *$ \\
\hline DxWQ & & ns & ns & ns & ns & ns & ns & $\mathrm{nS}$ & & ns & ns & ns & $*$ \\
\hline & & ns & ns & ns & ns & ns & ns & ns & ns & ns & ns & ns & $*$ \\
\hline WQxI & & ns & ns & ns & ns & ns & ns & ns & $*$ & $*$ & ns & ns & $* * *$ \\
\hline DxWQxI & & ns & ns & ns & ns & ns & ns & ns & ns & ns & $* *$ & ns & $*$ \\
\hline & & & & & & & 2009 & & & & & & \\
\hline Depth (D) & $0-25$ & 44.3 & 251.4 & 98.2 & 22.5 & 1.76 & 5.63 & 1.94 & 1.22 & 12.34 & 2.87 & 13.83 & 12.02 \\
\hline & $26-50$ & 35.7 & 269.5 & 89.7 & 19.4 & 2.06 & 6.28 & 1.52 & 1.31 & 11.74 & 2.70 & 12.86 & 11.55 \\
\hline & & ns & * & ns & $\mathrm{ns}$ & $*$ & $* *$ & $*$ & $* *$ & $* *$ & $\mathrm{~ns}$ & ns & ns \\
\hline Water quality (WQ) & FW & 27.6 & 83.9 & 70.5 & 16.4 & 0.82 & 2.36 & 1.56 & 0.40 & 12.68 & 2.99 & 12.14 & 4.97 \\
\hline & SW & 52.5 & 437.1 & 117.3 & 25.6 & 2.99 & 9.56 & 1.90 & 2.13 & 11.40 & 2.58 & 14.54 & 18.60 \\
\hline & & ns & & ns & ns & & $* *$ & $\mathrm{~ns}$ & & $* * *$ & $* * *$ & ns & $*$ \\
\hline Irrigation (I) & Il & 37.1 & 221.2 & 92.7 & 21.1 & 1.69 & $5.12 \mathrm{~b}$ & 1.62 & 1.03 & 12.03 & 2.79 & 13.44 & 9.21 \\
\hline & I2 & 42.1 & 249.9 & 93.2 & 20.6 & 1.85 & $5.79 \mathrm{~b}$ & 1.84 & 1.22 & 12.40 & 2.85 & 13.38 & 11.09 \\
\hline & $\mathrm{I} 3$ & 40.9 & 310.3 & 95.9 & 21.3 & 2.19 & $6.96 \mathrm{a}$ & 1.73 & 1.55 & 11.69 & 2.71 & 13.20 & 15.06 \\
\hline & & ns & ns & ns & $\mathrm{ns}$ & $\mathrm{ns}$ & $*$ & $\mathrm{~ns}$ & ns & ns & $\mathrm{ns}$ & ns & ns \\
\hline DxWQ & & ns & $*$ & $* * *$ & $* * *$ & $* *$ & * & $* *$ & $*$ & ns & ns & $*$ & ns \\
\hline DxI & & ns & ns & ns & ns & ns & ns & ns & ns & $* *$ & ns & ns & ns \\
\hline WQxI & & ns & ns & ns & ns & ns & & ns & ns & $\mathrm{ns}$ & ns & $*$ & ns \\
\hline DxWQxI & & ns & ns & ns & ns & ns & ns & ns & ns & ns & ns & ns & ns \\
\hline
\end{tabular}

${ }^{*} \mathrm{P} \leq 0.05 ;{ }^{* *} \mathrm{P} \leq 0.01 ;{ }^{* * *} \mathrm{P} \leq 0.001 ; \mathrm{ns}$, not significant. a,bValues in each column followed by a different letter are significantly different at $\mathrm{P}<0.05$ (SNK) 
quality water resulted in increased exchangeable $\mathrm{Na}$ on the exchange complex at the expense of exchangeable $\mathrm{Ca}$ and $\mathrm{Mg}$.

No significant differences were observed for all SSPE cations, ECe and SAR. Significant differences were found also for exchangeable $\mathrm{Na}$ and ESP value. In particular, for exchangeable $\mathrm{Na}$, the I3 treatment showed a decrease of $22 \%$ compared to the average of I1 and I2. Even if the 13 treatment applied a major rate of $\mathrm{Na}$, the higher water volume improved the mobility of this cation enhancing the leaching effect.

Regarding the interactions, no significant effects were found for all SSPE cations, ECe and SAR. Instead significant differences were observed for the interactions $D x W Q, W Q x I$ and $D x W Q x I$ for some exchangeable cations. In particular, $D x W Q$ interaction for exchangeable $\mathrm{Na}$ and ESP showed, once again, that the highest increases were recorded in the top layer (486 and 499\%, respectively, data not shown) compared to the deeper one. This behaviour is probably due to the lower $\mathrm{Na}$ affinity to the CEC compared to other exchangeable cations (Ca, $\mathrm{Mg}$ and $\mathrm{K}$ ). This phenomenon leads to higher $\mathrm{Na}$ concentrations in soil solution and, consequently, to higher Na transport along the soil profile, as reported by Pereira Lael et al. (2009).

For exchangeable $\mathrm{Na}, W Q x I$ interaction showed a constant positive trend (around $0.71 \mathrm{meq} 100 \mathrm{~g}^{-1}$, data not shown) in increasing irrigation volume FW regardless of irrigation treatment. However SW showed an increase from I1 to I2 in exchangeable Na with a maximum value of $4.5 \mathrm{meq} 100 \mathrm{~g}^{-1}$ (data not shown), while the application of $\mathrm{I} 3$ treatment determined a sharp reduction of Na to $2.6 \mathrm{meq} 100 \mathrm{~g}^{-1}$. Once again, this could be mainly due to an faster solute transport in the soil due to an higher leaching effect under I3.

The effect of $D x W Q x \mathrm{I}$ interaction for ESP is illustrated in Figure 3. In FW treatment, ESP showed low values in both layers regardless of the applied irrigation volumes. Instead, in SW, ESP values are quite constant from I1 to I2 and dramatically decrease in I3 for the top layer (14.4\%). In the deeper layer the reduction of ESP was less effective than the top layer, with a value of $11 \%$. These data confirmed that, due to irrigation and rainfall, the largest increase of cations, in particular of $\mathrm{Na}$, occurred in the top layer. In 2009, the average values of SSPE cations, ECe and SAR were lower than those recorded in 2007. This result was due to the lower irrigation volumes supplied in 2009 compared to 2007 (Table 2) and to the higher rainfall recorded in 2009 (128 mm) that supported a greater solute leaching below the sampled soil layers.

Compared to the previous year, no particular differences were detected about the relationships between ion concentrations. Gloaguen et al. (2007) reported that the behavior of $\mathrm{Na}$ in the soil solution depends predominantly by the balance between evaporation and precipitation, as well as on adsorption and desorption processes in the CEC. The same Authors observed increasing concentrations of soluble $\mathrm{Na}$ and SAR up to a depth of $2 \mathrm{~m}$ in a tropical soil after treatment by sewage effluent with a high concentration of $\mathrm{Na}$.

As regard the interactions, $D x W Q$ (Figure 4) shows that, compared to FW, the increase of EC value in SW was higher in the deeper layer than in the top one (307 and $222 \%$, respectively). Similar results were observed, within the same interaction, for all SSPE cations, with the exception for $\mathrm{K}$. This behavior was probably due to the higher rainfall recorded in 2009, that promoted the solute movement in deeper layer. These results are in agreement with those reported by Pereira Lael $e t$ al. (2009).

Figure 5 shows the effect of WQxI on SAR. In FW treatment, SAR showed a constant trend with a mean value of 2.3 regardless of irrigation volumes. However, in SW, I3 recorded a increase of 34\% compared to average of I1 and I2. This result is most likely to be linked to lower fruit weight of I3, shown in Figure 1, instead of higher amount of salts supplied with I3.
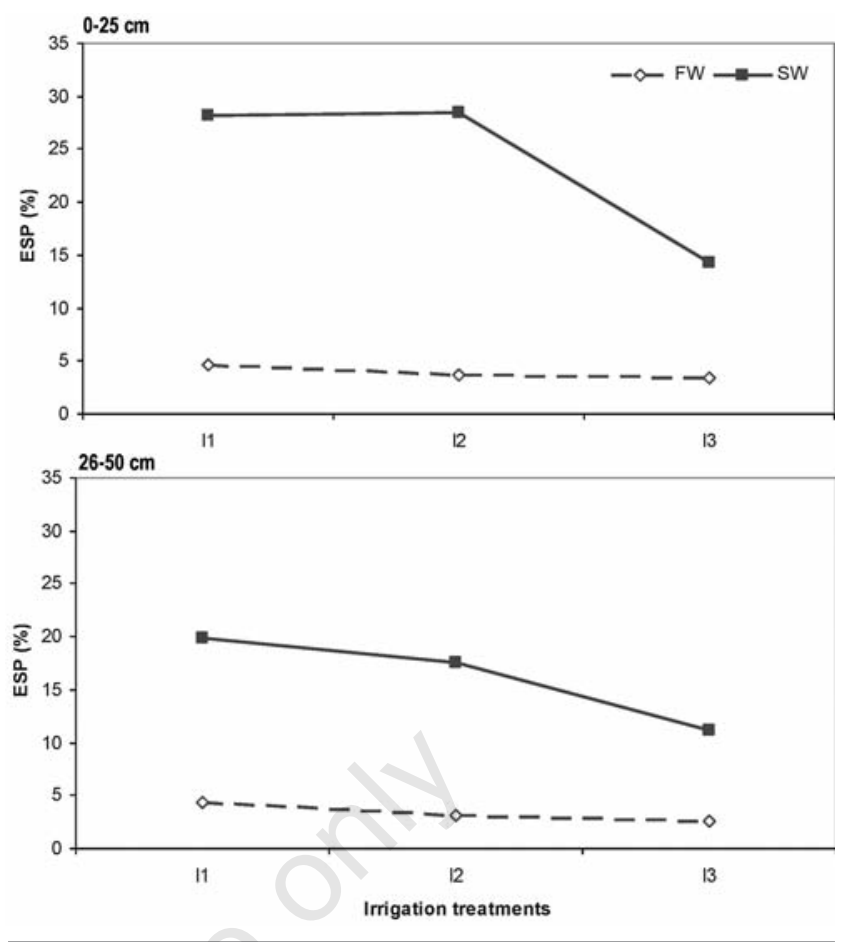

Figure 3. Effect of interaction depth $x$ water quality $x$ irrigation on ESP in 2007.

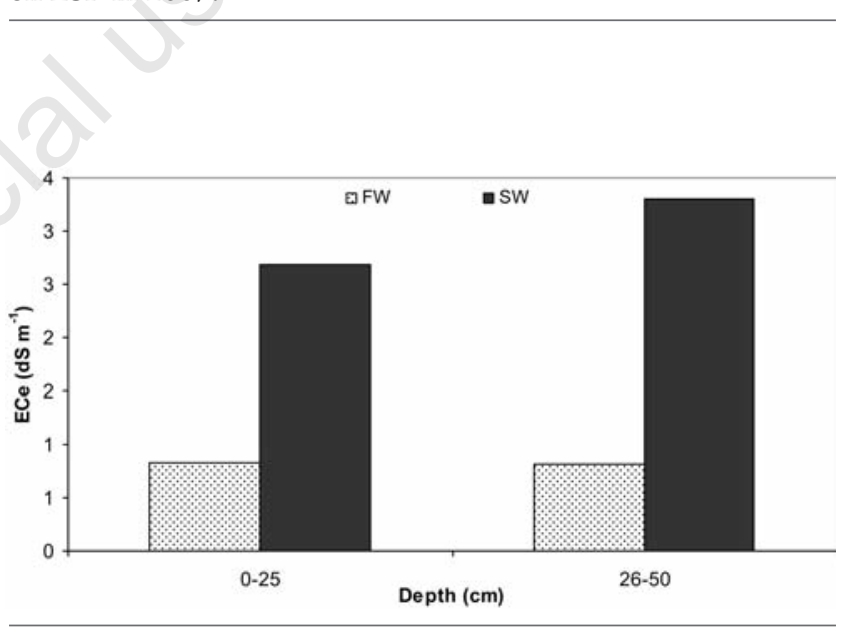

Figure 4. Effect of interaction depth $x$ water quality on EC in 2009.

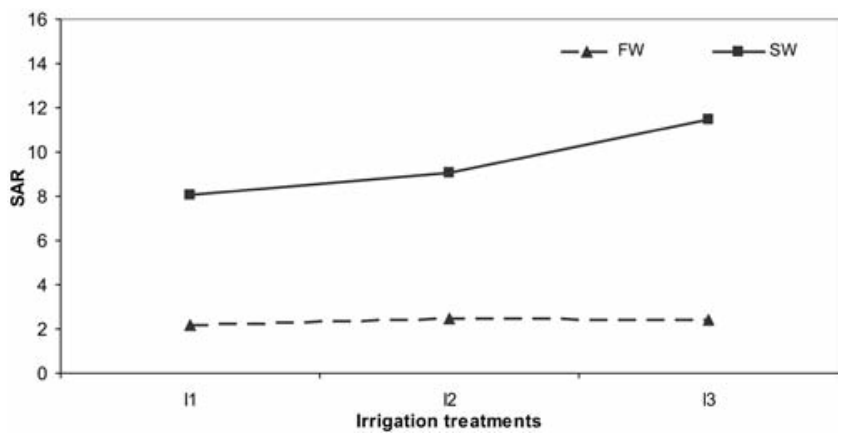

Figure 5. Effect of interaction of water quality $x$ irrigation on SAR in 2009. 


\section{Conclusion}

The principal goal of this research was to evaluate the possibility to use alternative water resources to irrigate a typical vegetable crop cultivated in Southern Italy. In the area where we carried out this research, it is common to have moderately saline water from wells that could be considered an important water resource. In a private farm two field researches were carried out with specific objectives in order to evaluate differential irrigation regimes and saline water effects. Two cycles of two-year rotation based on tomato and maize were cultivated and this paper reported the results obtained from tomato in the first and third year of continuous cultivation.

In general, the reduction of irrigation volume obtained decreasing by 25 and $50 \%$ of the water supplied respect to the optimum water requirement (100\% Etc), did not determine significant effect of reducing tomato yield. Moreover, there were no significant effects on fruit quality and soil chemistry. These results, quite unexpected, are probably due to the presence of a shallow water-table at $100 \mathrm{~cm}$ which, through capillary rise, contributed to fulfil the crop water requirements under limited irrigation treatments.

The application of irrigation with saline water (ECe of $6 \mathrm{dS} \mathrm{m}^{-1}$ ) on tomato $\mathrm{cv}$ Tomito did not reduce significantly the total and marketable yields compared with fresh water irrigation. These yields were obtained with an soil electrical conductivity that at the end of the cropping cycle was 4.95 and $2.99 \mathrm{dS} \mathrm{m}^{-1}$ for 2007 and 2009 , respectively, but the ECe mean of whole crop cycle, probably was around $2-3 \mathrm{dS} \mathrm{m}^{-1}$ in 2007 and $2 \mathrm{dS} \mathrm{m}^{-1}$ in 2009.

Moreover, the salinity of irrigation water reduced significantly the average marketable fruit weight (8\%) whereas did not affect the number of fruits. In particular, the lowest fruit weight and the highest SAR value were recorded for the I 3 treatment under SW, suggesting that the irrigation at $100 \%$ of ETm with saline water could determine a more deleterious effect compared to that detected at $50 \%$ of ETm, due to a major amount of applied salts. Dry biomass of fruits was not affected by salinity because the fruit size reduction was a consequence of reduction in water content in the fruit.

Finally, the TSS increased with salinity and hence the use of moderately saline irrigation water is recommended to improve fruit quality. In average, the continuous irrigation with saline water determined a soil ECe of about $3 \mathrm{dS} \mathrm{m}^{-1}$ whereas the SAR and ESP were about 14\% and $20 \%$, respectively. ECe value shows that the winter rains have been sufficient to leach significant amounts of salts avoiding that soil salinity could reaches salt stress threshold of the adopted tomato cultivar. The value of ESP of $20 \%$ can be taken to the limit of acceptability. However, the SAR and in particular the significant presence of $\mathrm{Ca}$ in the exchange complex reduces significantly the risk of deterioration of soil structure with particular reference to permeability hazard, as suggested by Rhoades et al. (1992).

Our results show that for the clay-loam soils widespread in the Jonical area of Metaponto it is possible to irrigate the Tomito cultivar with saline water up to $6 \mathrm{dS} \mathrm{m}^{-1}$ for a period of three years. However, we suggest that, especially when the winter rains are below the average, it should be necessary monitoring continuously the soil salinity before planting and, if the values of EC, SAR or ESP exceed the values achieved in this research, to stop the irrigation with saline water or adopt supplemental agronomic practices in order to reduce the risks to have lower crop production and to expose the soil to salinization processes.

\section{References}

Allen RG, Pereira LA, Raes D, Smith M, 1998. Crop evapotranspirationGuidelines for computing crop water requirements. FAO Irrigation and Drainage Paper No. 56. FA0 Publ., Roma, Italy.

Byari SH, Al-Sayed AR, 1999. The influence of differential irrigation regimes on five greenhouse tomato cultivars. 2 . The influence of differential irrigation regimes on fruit yield. Egyptian J. Hortic. Sci. 26:127-146.

Candido V, Miccolis V, Perniola M, 1999. Effects of irrigation regime yield and quality of processing tomato cultivars. Acta Hortic. 537:779-788.

Cuartero J, Fernández-Muñoz R, 1999. Tomato and salinity. Sci. Hortic.Amsterdam 78:83-125.

Cuartero J, Soria T, 1997. Productividad de tomates cultivados en condiciones salinas. Acta Hortic. 16:214-221.

Cucci G, Cantore V, Boari F, De Caro A, 2000. Water salinity and influence of SAR on yield and quality parameters in tomato. Acta Hortiv. 537:663-670.

Doorenbos J, Pruitt WO, 1977. Crop water requirements. FAO Irrigation and Drainage Paper No. 24 (revised) FAO Publ., Roma, Italy.

Dorais M, Papadopoulos AP, 2000. Greenhouse tomato fruit quality. Hortic. Rev. 29:239-319.

Dorais M, Papadopoulos AP, Gosselin A, 2001. Influence of electric conductivity management in greenhouse tomato yield and fruit quality. Agronomie 21:367-383.

Eltez RZ, Tüzel Y, Gül LA, Tüzel IH, Duyar H, 2002. Effects of different EC levels of nutrient solution on greenhouse tomato growing. Acta Hortic. 573:443-448.

Fereres E, Soriano MA, 2007. Deficit irrigation for reducing agricultural water use. J. Exp. Bot. 58:147-159.

Gloaguen TV, Forti MC, Lucas Y, Montes CR, Goncalves RAB, Herpin U, Melfi AJ, 2007. Soil solution of a Brazilian Oxisol irrigated with treated sewage effluent. Agr. Water Manage. 88:119-131.

Grange RI, Andrews J, 1994. Expansion rate of young tomato fruit growing on plants at positive water potential. Plant Cell Environ. 17:181187.

Kassam A, Smith M, 2001. FA0 methodologies on crop water use and crop water productivity. In: Expert Meet. on Crop Water Productivity, paper No. CWP-M07. Roma, Italy.

Jalali M, Merikhpour H, 2008. Effects of poor quality irigation waters on the nutrient leachimg and groundwater quality form sandy soil. Environ. Geol. 53:1289-1298.

Maas EV, 1986. Salt tolerance of plants. Appl. Agr. Res. 1:12-26.

Machado RMA, Rosario M, Oliveira G, Portas CAM, 2003. Tomato root distribution, yield and fruit quality under subsurface drip irrigation. Plant Soil 255:333-341.

Magán JJ, Gallardo M, Thompson RB, Lorenzo P, 2008. Effects of salinity on fruit yield and quality of tomato grown in soil-less culture in greenhouses in Mediterranean climatic conditions. Agr.Water Manage. 95:1041-1055.

Maggio A, De Pascale S, Angelino G, Ruggiero C, Barbieri G, 2004. Physiological response of tomato to saline irrigation in long-term salinized soils. Eur. J. Agr. 21:149-159.

Mizrahi Y, Taleisnik E, Kagan-Zur V, Zohas Y, Offenbach R, Matan E, Golan R, 1988. A saline irrigation regime for improving tomato fruit quality without reducing yield. J. Am. Soc. Hortic. Sci. 113:202-205.

Olympios CM, Karapanos IC, Ltonoudakis K, Apidianakis I, 2003. The growth, yield and quality of greenhouse tomato in relation to salinity applied at different stages of plant growth. Acta Hortic. 609:313320.

Page AL, Miller RH, Keeny DR, 1982. Methods of soil analysis, Part II. 2nd ed., American Society of Agronomy, Publ., Madison, WI, USA. 
Pereira Leal RM, Herpin U, da Fonseca AF, Firme LP, Montes CR, Melfi AJ, 2009. Sodicity and salinity in a brazilian oxisol cultivated with sugarcane irrigated with wastewater. Agr. Water Manage. 96:307316 .

Reina-Sanchez A, Romero-Aranda R, Guartero J, 2005. Plant water uptake and water use efficiency of greenhouse tomato eultivars irrigated with saline water. Agr. Water Manage. 78:54-66.

Rhoades JD, Kandlah A, Marshall AM, 1992. The use of saline waters for crop production. FAO Irrigation and Drainage paper No. 48. FA0 Publ., Roma, Italy.

SAS, 1998. SAS/STAT User's Guide, ver. 6.12. SAS Inst. Inc., Cary, NC, USA.

Sonneveld C, van der Burg AMM, 1991. Sodium chloride salinity in fruit vegetable crops in soilless culture. Neth. J. Agr. Sci. 39:115-122.
Sunitha N, Basavaraja PK, Dhananjaya BN, Narasimhareddy PN, Sudhir K, 2010. Characterization of salt-affected soils on Dodda Seebi tank command area. Karnataka J. Agr. Sci. 23:354-357.

UNESCO/FAO, 1963. Bioclimatic map of the Mediterranean zone. Available from: http://unesdoc.unesco.org/images/0006/000682/ 068203eo.pdf

van Ieperen W, 1996. Effects of different day and night salinity levels on vegetative growth, yield and quality of tomato. J. Hortic. Sci. 71:99100.

Yurtseven E, Kesmez GD, Untukara A, 2005. The effects of water salinity and potassium levels on yield, fruit quality and water consumption of native center anatolian tomato species (Lycopersicon esculentum). Agr. Water Manage. 78:128-135. 